\title{
The Prolactin Gene Expression Variance in Marshes and Riverine Buffalos in Iraq
}

\author{
*DhiaHussain Jassim AL-Delemi, AlaaKamil Abdulla Al-Gewary, Basim HameedAbd Ali \\ Department of Pathology, Medical Foundation and Clinic, Nigeria
}

Submission: May 10, 2016; Published: August 11, 2016

*Corresponding author: Dhia Hussain Jassim, Department of Surgery and Obstetrics, College of Veterinary Medicine, University of AL-Qadisiya, Iraq.

\begin{abstract}
The study area consisted of eight stations in southern Iraqi marshes in the Missan governorate, and six stations in the Al-Qadisiya and Al-Najaf governorates. The southern Iraqi marshes had the proper environment for the culture of the riverine buffalo breed, yet the water buffalo prefer the middle area [1], because the molecular information of the local buffalo in Iraq is very rare [2]. The present study selection is the improvement of milk yield with the advances in molecular biology, the identification of the underlying genes by quantitative (rt-PCR) technique responsible for the efficiency of the prolactin (PRL-R)gene expression and to better understand the actions of mammary gland gene expression on milk production in the two buffalo breeds in Iraq, by determining levels of the PRL-R gene expression in somatic cells in the mammary gland by random milk samples of swamp and riverine buffalos during first medal and last lactation period. The results showed high expression of PRL-R gene in last lactation period of riverine buffalo than in swamp buffalo breed, and hence this gene may have potential direct or indirect effect on milk production. The transcription levels of PRL-R gene in the milk of swamp buffalo were found to be significantly down regulated in the first stage of lactation period, but were up-regulated in second stage of this period, and this regulation significantly decreased in the last period. In the riverine buffalo, the levels were very down regulated in the first stage of and curved to a highly induced regulation in second and late lactation period.
\end{abstract}

Keywords: Buffalos; Prolactin; Gene Expression

Abbreviations: PRL-R: Prolactin Regulation; GAPDH: Glyceraldehyde 3-Phosphate Dehydrogenase; CMT: California Mastitis Test; PBS: Phosphate Buffer Slain; OD: Optical Density

\section{Introduction}

Buffaloes are considered one of the animals that are wide spread in the marshes area in the south of Iraq [1,3]. It is an important dairy animal, because of the opportunities of milk production, despite feeding on low quality roughage [4-6]. The domestic buffalo belongs to the family Bovidae, sub family Bovinae, genus bubalis $[7,8]$. The buffalo population in Iraq exists as two main types - swamp and river buffalo $[9,10]$. In the present study, we evaluated the PRL-R gene expression in milk somatic cells during lactating period, by using the quantitative real-time PCR (qPCR), which is considered the gold standard for gene expression analyses because of its high sensitivity, specificity, and reproducibility [11]. The prolactin hormone and other environmental factors stimulate the growth of the mammary gland $[12,13]$. This Prolactin hormone binds to specific receptor (PRL-R) which is responsible for the hormonal action [14-16].

In cattle, two isoforms of PRL-R have been found, resulting from alternative splicing: long form, with a length of 557 amino acids, and a short one, with a length of 272 amino acids. The PRL-R gene, mapped on the bovine chromosome 20 , is originally described as having 10 exons [17-19]. These polymorphic sites in the bovine PRL-Rgene were discovered in 2006 [20], while the first polymorphism in the bovine prolactin receptor gene was identified in 2005 , in the region involved in the alternative splicing of the transcript [21-23]. This gene coding for bovine PRL-R was mapped to chromosome 20 in cattle and chromosome 19 in buffalo [24]. Most transcripts of the PRL-R gene are processed for the synthesis of PRL-R mRNA in the epithelial cells of mammary ducts and alveoli [25-27], and have nine exons that code for a polypeptide of 581 amino acids [22], yet the PRL-R belongs to type I transmembrane receptor family and structurally resembles the class I cytokine receptor super-family $[28,17]$.

The aim of this study is to examine the changes of mRNA expression using quantitative real-time polymerase chain reaction, because this technique is considered the gold standard 
for gene expression analyses because of its high sensitivity, specificity, and reproducibility [11], with (GAPDH) as a reference gene which has been found to vary with tissue type, developmental stage, and environmental stimuli [29]. In this study, we attempt to examine the prolactin receptor gene expression level in milk somatic cells or lactating mammary gland of cows during early, mid and last lactation period, in both swamp and riverine buffalo breeds. The milk collection is routinely performed and is less expensive and more easily accomplished than blood collection according to the study of Yang FL and Li XS [30].

\section{Materials and Methods}

\section{Animals and milk samples}

Twenty adult, lactating buffaloes were selected from local breed swamp $(\mathrm{n}=10)$ from the middle (Diwaniya and Al-Najaf), and riverine buffalos $(n=10)$ were collected from south of Iraq (Missan and ThiQar). The milk samples were determined to be free of mastitis defect according to routine testing by CMT (california mastitis test). The volume of the samples collected from each animal was $50 \mathrm{ml}$ during the three stages of lactation period, which are classified on physiochemical characteristics of milk samples according to stage of lactation period in swamp buffalo. Accordingly, first stage (S1) is 10-100 days, second stage (S2) is 101-180 days and third stage (S3) is 181 days. In riverine buffalo, the first stage (R1) was for 10-100 days, second stage (R2) for 101-180 days and third stage(R3) for 181 days [31], with minor modifications.

These samples were placed in ice box for 3-5hrs, and later subjected to Centrifugation at $12000 \mathrm{rpm}$ for $10 \mathrm{~min}$ at $4^{\circ} \mathrm{C}$. The resulting supernatant containing the hard fat layer was aspirated and discarded, leaving a $5 \mathrm{ml}$ residual fluid at the bottom of the tube. PBS (phosphate buffer slain) (5ml) was added to the fluid and was re-suspended and centrifuged again at $1200 \mathrm{rpm}$ for $5 \mathrm{~min}$ at $4^{\circ} \mathrm{C}$. The supernatant was discarded and $1 \mathrm{ml}$ of the residual fluid at the bottom was transferred by the pipette into $1.5 \mathrm{ml}$ free RNAse eppendorf tube and centrifuged at $1200 \mathrm{rpm}$ for $5 \mathrm{~min}$ at $4^{\circ} \mathrm{C}$. The pellet obtained was washed with PBS three times, and stored at -70 to $-80^{\circ} \mathrm{C}$ in deep freeze system, until total RNA extraction, according to method of Sigl T et al. [32].

Table 1: The PRL-R and GAPDH genes primers with their sequences, product size and PCR conditions.

\begin{tabular}{|c|c|c|c|}
\hline Primer & Sequences & Product size (bp) & PCR conditions \\
\hline GAPDH (F) & $\begin{array}{c}\text { 5'ACAGTCAAGGCAGAGAACGG-3' }^{\prime} \\
\text { 5'-TGCGCTCACCTGACAATCTT-3' }\end{array}$ & 501 & $\begin{array}{c}2 \mathrm{~min} .95^{\circ} \mathrm{C}, 30 \mathrm{sec} .95^{\circ} \mathrm{C}, 30 \mathrm{sec} . \\
58^{\circ} \mathrm{C}, 60 \mathrm{sec} .72^{\circ} \mathrm{C}, 5 \mathrm{~min} .72^{\circ} \mathrm{C}\end{array}$ \\
\hline PRL-r (F) & $\begin{array}{c}5^{\prime} \text {-CTGCTGATCAGTGCCTGACA-3' } \\
\text { 5'-ATGAGTCCCATCCATCCCA-3' }\end{array}$ & 509 & $\begin{array}{c}2 \mathrm{~min} .95^{\circ} \mathrm{C}, 30 \mathrm{sec} .95^{\circ} \mathrm{C}, 30 \mathrm{sec} . \\
58^{\circ} \mathrm{C}, 60 \mathrm{sec} .72^{\circ} \mathrm{C}, 5 \mathrm{~min} .72^{\circ} \mathrm{C}\end{array}$ \\
\hline
\end{tabular}

\section{Primers}

Two primer pairs were designed using the Primer Premier 5.0 software (http://www.premierbiosoft.com); the Housekeeping gene is GAPDH gene primer and the other primer used for PRL-R

\section{RNA extraction and purification}

Table 2: The value of total RNA concentration by SP-3000 Nano (UV/V) Spectrophotometer.

\begin{tabular}{|c|c|c|c|}
\hline \multirow{2}{*}{$\begin{array}{c}\text { Buffalo } \\
\text { breeding } \quad \text { samples }\end{array}$} & First stage & Sec. stage & Third stage \\
\cline { 2 - 4 } & $91.3 \pm 0.633$ & $92.2 \pm 1.103^{*}$ & $90.6 \pm 1.275$ \\
\hline Swamp breed & $91.8 \pm 1.38$ & $90.3 \pm 1.247$ & $88.6 \pm 1.087$ \\
\hline Riverine breed & &
\end{tabular}

\section{${ }^{*}$ ) significant differences}

The total RNA was extracted from somatic cells using Trizol® Reagent by AMBION/RNA (LIFE TECHNOLOGIES Ltd.,) CALIFORNIA, according to the manufacturer's protocol. The integrity of total RNA extracted was verified by agarose gel electrophoresis by NANOPAC-300 (CLEAVER SCIENTIFIC Ltd.) UK. The RNA was quantitated using SP-3000 Nano (UV/ Vis Spectrophotometer, OPTIMA Tokyo) JAPAN, and the purity and quantity of the extracted total RNA were assessed, with the optical density (OD) ratio of OD260/OD280 being 1.8 to 2.0 for all samples (Table 2). To remove the contamination from gene as a target gene (Table 1). The specificity of the primer sets designed was confirmed by sequencing analysis of amplicon (http://dx.doi.org/10.3168/jds.2012-6437). genomic DNA, we used the DNase I (Ta- KaRa) Kit.

The First-strand cDNA was synthesized from $1500 \mathrm{ng}$ of RNA using the Cloned AMV (INVETROGEN®) First-Strand cDNA Synthesis Kit (USA). The Reverse Transcriptase PCR was performed according to manufacturer's protocol, by using PCR system (MultiGeneOptiMax Thermal Cycler TC9610 /TC9610230), MIDSCI®, USA at the biotechnology college of Al-Qadissiya university. Finally, the samples were stored at $-20^{\circ} \mathrm{C}$ until quantitative real time PCR (rt- PCR) was performed.

\section{cDNA syntheses}




\section{Quantitative real-time PCR}

The q (rt-PCR) was carried out as described by Priyanka S et al. [33], for the relative expression of target genes in somatic cells of swamp buffaloes, in comparison with riverine buffaloes breed. The $\Delta \mathrm{CT}$, using a reference gene method can be used by normalizing gene expression of target (PRL-R) genes with the gene expression of housekeeping (GAPDH) gene as a reference gene, by using the following formula:-

Expression value (Fold yield) $={ }^{2 \wedge} \mathrm{CT}$ (reference) - CT (target)

The mean of CT numbers for target genes was normalized with reference (GAPDH) gene expression and was determined by using the Microsoft excel according to Vandesompele J et al. [34], and evaluation of these results was done [35].

\section{Performance of $q$ (real time-PCR)}

The SYBER Green I based two-step reaction of $\mathrm{q}(\mathrm{rt}-\neg \mathrm{PCR})$ was performed according to manufacturer's protocol of Power SYBR ${ }^{\circ}$ Green PCR Master Mix kit (applied biosystem ), California, USA and Exicycler ${ }^{\mathrm{TM}} 96$ Real-Time Quantitative Thermal Block instrument(Bioneer), Korea, at the veterinary hospital laboratory of Al-najaf, according to the method described by Chen HF [36]. Therefore two q (rt-PCR) master mixes were prepared, for the PRL, and GAPDH genes, as following: $20 \mu \mathrm{L}$ of total volume cDNA template for target genes from cDNA template $(10 \mu \mathrm{L})$, forward $(2 \mu \mathrm{L})$ and reverse $(2 \mu \mathrm{L})$ primers and DEPC water $(6 \mu \mathrm{L})$. These master mixes were added into Power SYBR $\AA$ Green PCR Master Mix kit q (rt-PCR) PreMix tube, and then Exicycler ${ }^{\mathrm{TM}} 96$ Real-Time Quantitative thermal Block instrument was used for relative quantification, according to kit instruction.

\section{Statistical Analysis}

All the values are expressed as mean \pm Se. Data of results were analyzed using student t-test and appropriate $\mathrm{p}$-values of less than $0.05(\mathrm{P}<0.05)$ were considered as statistically significant [37].

\section{Results}

In our study, the value of total RNA concentration (Table 2) was highly different $(94.374 \pm 3.07 \mathrm{ng} / \mu \mathrm{l})$ in somatic cells of the mammary gland. Its total RNA samples were used in cDNA synthesis step, by using First-Strand cDNA Synthesis Kit.

\section{The relative quantitative real time-PCR}

Data analysis of SYBR green I based rt-PCR assay was divided into primer efficiency estimation and relative quantification of PRL-R gene expression level, which was normalized by housekeeping gene expression (GAPDH). The Ct values of GAPDH are 23.2676 in swamp breed and 23.4184 in riverine breed, obtained as the result of normalizing the PRL-R gene expression by the delta CT method using a Reference Gene [38]. In swamp buffalo, the expression value of PRL-R gene during lactation period which declines in first stage is 0.6145 , second stage upregulation is 1.653 and decreased regulation is 1.1272 in the last period, while in riverine buffalo, this expression has very low regulation (0.4045) in first stage of lactation and curved to a highly induced regulation in the second (2.1312) and late lactation period (4.4201) in mammary gland (Table 3) (Figure $1 \& 2)$.

Table 3: The mean of Ct values and expression value of the PRL-R gene in the somatic cells of swamp breed and riverine breed buffalo.

\begin{tabular}{|c|c|c|c|c|c|}
\hline \multirow{2}{*}{$\begin{array}{l}\text { Buffalo } \\
\text { breeding }\end{array}$} & \multicolumn{3}{|c|}{ Mean \pm Se. of CT values } & \multirow{2}{*}{$\Delta \mathrm{CT}$} & \multirow{2}{*}{$\begin{array}{c}\text { Expression } \\
\text { value }\left(2^{\wedge} \Delta \mathrm{CT}\right)\end{array}$} \\
\hline & Lactation period & $\begin{array}{l}\text { PLR-R (Target) } \\
\text { gene }\end{array}$ & $\begin{array}{l}\text { GAPDH-R (Reference) } \\
\text { gene }\end{array}$ & & \\
\hline \multirow{3}{*}{ Swamp breed } & S1-group & 22.5652 & 23.2676 & -0.7024 & 0.6145 \\
\hline & S2-group & 23.9927 & 23.2676 & 0.7251 & $1.653^{*}$ \\
\hline & S3-group & 23.4404 & 23.2676 & 0.1728 & 1.1272 \\
\hline \multirow{3}{*}{ Riverine breed } & R1-group & 22.1127 & 23.4184 & -1.3057 & 0.4045 \\
\hline & R2-group & 24.5101 & 23.4184 & 1.0917 & $2.1312^{*}$ \\
\hline & R3-group & 25.5625 & 23.4184 & 2.1441 & $4.4201^{* *}$ \\
\hline
\end{tabular}

$\left(^{*}\right)$ significant differences, $\left.{ }^{* *}\right)$ significant differences.

Experimental groups $(n=10)$ according to days of lactation period

$\mathrm{S} 1=$ Swamp buffalo in 10-100

S2= Swamp buffalo in 100-180

S3= Swamp buffalo in $>180$

\author{
R1= Riverine buffalo in 10-100 \\ R2= Riverine buffalo in 100-180 \\ R3= Riverine buffalo in $>180$
}




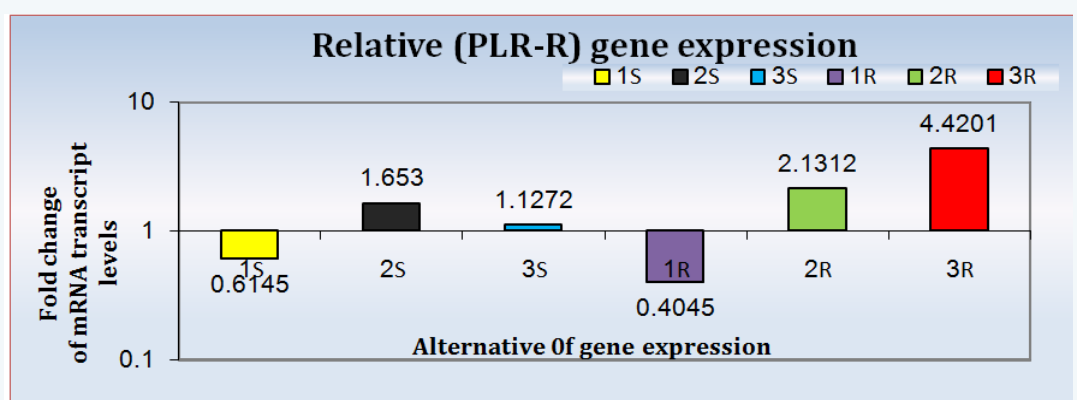

Figure 1: The mean of fold change of mRNA transcript levels to the PRL-R gene and GAPDH-R gene in swamp, and riverine buffalo breed.
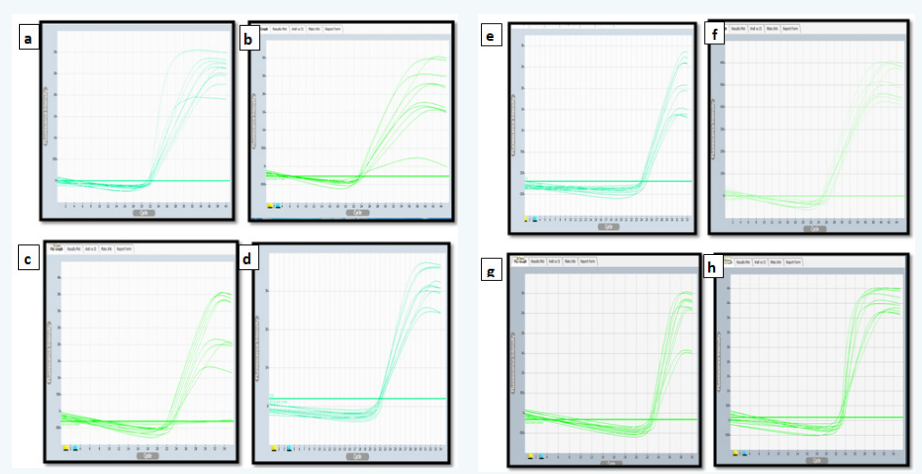

Figure 2: Real Time PCR Amplification plot for PRL-R gene-(S) swamp breed, (R) riverine breed:

[a] First period (S1),

[b] Second period (S2),

[c] Third period (S3),

[d] First period (R1)

[e] Second period (R2),

[f] Third period (R3),

[g] GAPDH gene in swamp breed and

[h] GAPDH gene in riverine breed by (Excecycler 96$) \circledR$ system.

\section{Discussion}

In mammals, the hormone prolactin (PRL) is best known for its role in the regulation of lactation [39-41], and it also has important functions like the development of mammary gland, affecting milk yield and composition [42-45]. Also according to Imagawa $\mathrm{M}$ et al. [13], this hormone is a stimulant for the growth of mammary ductal and alveolar cells by binding to PRL-R. Yet, the physiological functions of the PRL hormone to induce lactation are through the effect of PRI-R [46]. The prolactin receptor (PRL-R) gene was reportedly associated with milk protein and milk fat yields in the swamp buffalo [47]. The statistic significance of the study [48] confirmed the associations between PRL-R and milk production in livestock.

Therefore the results of the previous study confirmed the up-regulation of PRL-R gene expression in last lactation period of riverine buffalo (4.4201) more than in the swamp buffalo, which are down-regulated (1.1272) in this period. These results are in agreement with the previous studies [46,49-51] and also support the concept that the PRL-R's higher sensitivity to PRL during lactation period may be associated with an increase in subsequent milk yield in riverine buffalo more than the swamp buffalo. The previous studies [52] observed that the swamp buffalo produces relatively small quantities of milk, while [53] it was recorded that in the riverine breeds, milk yield is high, at about six to seven liters per day.

In the mammary gland of lactating mice, the PRL- $R$ is highly expressed both at the end of pregnancy and during lactation [54]. PRL-R1 mRNA expression is highly induced in the mammary gland during late pregnancy and abruptly declines on the first day of lactation for the HT rats [55], but this observation disagrees with the study of Auchtung TL et al. [40], that recorded that a short day photoperiod was associated with reduced PRL, whereas milk yield and expression of PRL-R mRNA in lymphocytes and mammary tissue were increased. The swamp buffalo produces low amount of milk (1.0-1.5 litres per day), so they are not heavily used in milk production [52], but the milk yield of Indian riverine breeds, is about 6-7 liters per day [53]. The PRL-R numbers begin to decrease in early pregnancy and are maintained at a low level until late pregnancy [56].

\section{Conclusion}

The data normalization of the reference gene (GAPDH) was done with PRL-R gene expression in milk somatic cells of the two lactating local buffalo breeds. In the present study, we compared 
the transcription levels of PRL-R gene in milk of swamp buffalo which were found to be significantly down regulated in first stage of lactation period, but were up-regulated in second stage of this period, and this regulation significantly decreased in the last period, while in riverine buffalo this expression is very down regulated in the first stage of lactation and curved to a highly induced regulation in second and late lactation period.

\section{References}

1. Al-Saedy J, Al-Fartosi K (2011) Iraqi buffalo status and perspectives. Buffalo Newsletter, International Buffalo Federation (IBF).

2. Hussain DA, Ghareeb AM, Salo WH (2014) Evaluation of DNA polymorphism in bovine growth hormone gene by PCR-RFLP method. International journal of science and nature 5(3): 407-411.

3. Al Fartosi KG (2010) the role of buffaloes breeding in the development of nation's economic. The first conference of Iraqi buffaloes. Ministry of Agriculture, Iraq, p. 22-212.

4. Thomas CS (2004) Milking management of dairy buffaloes. Acta Universitatis Agriculturae Sueciae, Swedish University of Agricultural Sciences, Uppsala, Sweden. pp: 7-9.

5. Bandyopadhyay AK, Ray PR, Ghatak PK (2003) Effective utilization of buffalo milk for manufacturing dairy products. $4^{\text {th }}$ Asian Buffalo Congress Lead Paper, 19.

6. Andreas E, Sumantri C, Nuraini H, Farajallah A, Anggraeni A (2010) Identification of GH/ ALUI genes polymorphisms in Indonesian buffalo. J Indones Trop Anim Agric 35(4): 215-221.

7. Al Obaidi S, Abid HS, Al Fartosi K, Haider SA, Radhi Z, et al. (2007) Water Buffalo in the Iraqi Marshes. Nature Iraq, pp: 4-8.

8. IUCN (World Conservation Union) Red List of Threatened Species (2007) Bubalusbubalis.

9. Drost $M(2007)$ Bubaline versus bovine reproduction. J Theriogenology 68(3): 447-449.

10. Borghese A, Mazzi M (2005) Buffalo Population and Strategies in the World. In: buffalo production and research. FAO of the USA pp:23-24.

11. Yadav P, Singh DD, Mukesh M, Kataria RS, Yadav A, et al. (2012) Identification of suitable housekeeping genes for expression analysis in mammary epithelial cells of buffalo (Bubalusbubalis) during lactation cycle. Livest Sci 147(1-3): 72-76.

12. Borellini F, Oka T (1989) Growth control and differentiation in mammary epithelial cells. Environ Heal Pers 80: 85-99.

13. Imagawa W, Bandyopadhyay GK, Nandi S (1990) Regulation of mammary epithelial cell growth in mice and rats. Endoc Rev 11: 494523.

14. Kelly PA, Bachelot A, Kedzia C, Hennighausen L, Ormandy CJ, et al. (2002) The role of prolactin and growth hormone in mammary gland development. Mol Cell Endocrinol 197(1-2): 127-131.

15. Vaclavicek A, Hemminki K, Bartram CR, Wagner K, Wappenschmidt B, et al. (2006) Association of Prolactin and Its Receptor Gene Regions with Familial Breast Cancer. Journal of Clinical Endocrinology \& Metabolism 91(4): 1513-1519.

16. Fleenor D, Arumugam R and Freemark M (2006). Growth hormone and prolactin receptors in adipogenesis: STAT-5 activation, suppressors of cytokine signaling, and regulation of insulin-like growth factor I. Horm Res 66(3): 101-110.

17. Kelly PA, Dijane J, Postel-Vinay MC, Edery M (1991) the prolactin/ growth hormone receptor family. Endocr Rev 12(3): 235-251.
18. Fontanesi L, Scotti E, Dolezal M, Lipkin E, Dall'Olio S, et al. (2007). Bovine chromosome 20: milk production QTL and candidate gene analysis in the Italian Holstein-Friesian breed. Ital. J. Anim. Sci. 6(1): 133-135.

19. Hayes H, Le Chalony C, Goubin G, Mercier D, Payen E, et al. (1996) Localization of ZNF164, ZNF146, GGTA1, SOX2, PRLR and EEF2 on homeologous cattle, sheep, and goat chromosomes by fluorescent in situ hybridization and comparison with human gene map. Cytogenet Cell Genet 72(4): 342-346.

20. Viitala S, Szyda J, Blott S, Schulman N, Lidauer M, et al. (2006) The Role of the Bovine Growth Hormone Receptor and Prolactin Receptor Genes in Milk, Fat and Protein Production in Finnish Ayrshire Dairy Cattle. Genetics 173(4): 2151-2164.

21. Brym P, Kamiński S, Wójcik E (2005) Polymorphism within the bovine prolactin receptor gene (PRLR). Anim Sci Pap Rep 23(1): 61-66.

22. Kossiakoff AA, Somers W, Ultsch M, Andow K, Muller YA, et al. (1994) Comparison of the intermediate complexes of human growth hormone bound to the human growth hormone and prolactin receptors. Prot Sci 3(10): 1697-1705.

23. Iso-Touru T, Kantanen J, Li MH, Gizejewski Z, Vilkki J (2009) Divergent evolution in the cytoplasmic domains of PRLR and GHR genes in Artiodactyla. BMC Evol Biol 9: 172.

24. Amaral ME, Grant JR, Riggs PK, Stafuzza NB, Filho EA, et al. (2008) A first generation whole genome $\mathrm{RH}$ map of the river buffalo with comparison to domestic cattle. BMC Genomics 9:631.

25. Mizoguchi Y, Kim JY, Sasaki T, Hama T, Sasaki M, et al. (1996) Acute expression of the prolactin receptor gene after ovariectoy in midpregnant mouse mammary gland. Endocr J 43(5): 537-544.

26. Nagano M, Kelly PA (1994) Tissue distribution and regulation of rat prolactin receptor gene expression. J BiolChem 269(18): 13337-13345.

27. Bera TK, Hwang S, Swanson SM, Guzman RC, Edery M, et al. (1994) In situ localization of prolactin receptor message in the mammary glands of pituitary-isografted mice. Mol Cell Biochem 132(2): 145-149.

28. Boutin JM, Jolicoeur C, Okamura H, Banville D, Dusanter-Fourt I, et al. (1988). Cloning and expression of the rat prolactin receptor, a member of the growth hormone/prolactin receptor gene family. Cell 53(1): 6977.

29. Zheng WJ, Sun L (2011) Evaluation of housekeeping genes as references for quantitative real time RT-PCR analysis of gene expression in Japanese flounder (Paralichthysolivaceus). Fish Shellfish Immunol 30(2): 638-645.

30. Yang FL, Li XS (2013) Somatic cell counts positive effects on the dna yield extracted directly from murrah buffalo milk, JCRSDJ 1(5): 392395.

31. Zaman G, Goswami RN, Aziz A (2007) Milk constituent of swamp buffalo of Assam. Buffalo Bulletin 26(1).

32. Sigl T, Meyer HHD, Wiedemann S (2012) Gene expression of six major milk proteins in primary bovine mammary epithelial cells isolated from milk during the first twenty weeks of lactation. Czech J Anim Sci 57(10): 469-480.

33. Priyanka S, Jayaram P, Sridaran R, Medhamurthy R (2009) Genomewide gene expression analysis reveals a dynamic interplay between luteotropic and luteolytic factors in the regulation of corpus luteum function in the bonnet monkey (Macaca radiata). Endocrinology 150(3):1473-1484.

34. Vandesompele J, Paepe AD, Speleman F (2002) Elimination of primer dimer artifacts and genomic amplification using a two-step SYBR green I real-time RT-PCR. Anal Biochem 303(1): 95-98. 
35. Erickson HS, Albert PS, Gillespie JW, Rodriguez-Canales J, Linehan MW, et al. (2009) Quantitative RT-PCR gene expression analysis of laser micro dissected tissue samples. J Nat Protoc 4(6): 902-922.

36. Chen HF, Jeung EB, Stephenson M, Leung PC (1999) Human peripheral blood mononuclear cells express gonadotropin-releasing hormone (GnRH), GnRH receptor, and interleukin-2 receptor gamma-chain messenger ribonucleic acids that are regulated by $\mathrm{GnRH}$ in vitro. J Clinical Endo Metab 84(2): 743-750.

37. SAS (2010) SAS/STAT User's guide for personal computers. SAS Institute Inc. USA.

38. Bio-Rad Laboratories, Inc. (2006) Real-Time PCR Applications Guide.

39. Bole-Feysot C, Goffin V, Edery M, Binart N, Kelly PA (1998) Prolactin (PRL) and its receptor: actions, signal transduction pathways and phenotypes observed in PRL receptor knockout mice. Endocr Rev 19(3): 225-68.

40. Auchtung TL, Rius AG, Kendall PE, McFadden TB, Dahl GE (2005) Effects of photoperiod during the dry period on prolactin, prolactin receptor and milk production of dairy cows. J Dairy Sci 88(1): 121-127.

41. Lee SA, Haiman CA, Burtt NP, Pooler LC, Cheng I, et al. (2007) A comprehensive analysis of common genetic variation in prolactin (PRL) and PRL receptor (PRLR) genes in relation to plasma prolactin levels and breast cancer risk: the Multiethnic Cohort. BMC Medical Genetics 8: 72.

42. Kumari AR, Singh KM, Soni KJ, Patel L, Chauhan RK, et al. (2008) Genotyping of the polymorphism within exon 3 of prolactin gene in various dairy breeds by PCR RFLP. Arch Tierz 51(3): 298-299.

43. Mehmannavaz Y, Amirinia C, Bonyadi M, Torshizi RV (2009) Effects of bovine prolactin gene polymorphism within exon 4 on milk related traits and genetic trends in Iranian Holstein bulls. African Journal of Biotechnology 8(19): 4797-4801.

44. Dybus A, Grzesiak W, Kamieniecki H, Szatkowska I, Sobek Z, et al. (2005) Association of genetic variants of bovine prolactin with milk production traits of black-and-white and jersey cattle. arch tierz 48(2): 149-156.

45. Alipanah M, Kalashnikova LA, Rodionov GV (2007) Polymorphism prolactin loci in Russian cattle. Journal of Animal and Veterinary Advances 6(6): 813-815.
46. Lü A, Hu X, Chen H, Jiang J, Zhang C, et al. (2009) Single nucleotide polymorphisms in bovine PRL gene and their associations with milk production traits in Chinese Holsteins. Mol Biol Rep 37(1): 547-51.

47. Javed R, Gautam SK, Vijh RK, Tantia MS (2011) Characterization of PRLR and PPARGC1A genes in buffalo (Bubalus bubalis). Genet Mol Biol 34(4): 592-594.

48. Deepika, Salar RK (2014) Polymorphism studies of Prolactin Receptor (PRLR) gene in Indigenous Grey Cattle breeds of India. DHR International Journal of Biomedical and Life sciences 5(1).

49. Javed R , Gautam SK, Vijh RK, Tantia MS (2011) Characterization of PRLR and PPARGC1A genes in buffalo (Bubalus bubalis). Genetics and Molecular Biology 34(4): 592-594.

50. Hou JX, Fang F, An XP, Yan Y, Ma T, et al. (2014) polymorphisms of PRLR and FOLR1 genes and association with milk production traits in goats. Genetics and Molecular Research 13(2): 2555-2562.

51. Saunier E, Dif F, Kelly PA, Edery M (2003) Targeted Expression of the Dominant-Negative Prolactin Receptor in the Mammary Gland of Transgenic Mice Results in Impaired Lactation. Endocrinology 144(6): 2669-2675.

52. Chantalakhana C, Falvey L (1999) Smallholder dairying in the tropics. ILRI (International Livestock Research Institute), Nairobi, Kenya pp.462.

53. Zicarelli L (2001) Buffalo milk production world-wide. VI World Buffalo Congress, (Volume 1), pp. 202-230.

54. Lesueur L, Edery M, Ali S, Paly J, Kelly PA, et al. (1991) Comparison of long and short forms of the prolactin receptor on prolactin-induced milk protein gene transcription. Proc Natl Acad Sci USA 88(3): 824828

55. Dybus A, Grzesiak W, Kamieniecki H, Szatkowska I, Sobek Z, et.al. (2005) Association of genetic variants of bovine prolactin with milk production traits of Black-and-White and Jersey cattle. Arch Tierz 48(2): 149-156.

56. Mancini T, Casanueva FF, Giustina A (2008) Hyperprolactinemia and prolactinoma. Endocrinology and Metabolism Clinics of North America 37(1): 67-99. 